\title{
Article \\ Mineralization of High-Concentration Aqueous Aniline by Hybrid Process
}

\author{
Haibing Zhang *, Yasong Zhou, Shaohui Guo, Zhipu Wang and Qing Wang
}

check for

updates

Citation: Zhang, H.; Zhou, Y.; Guo,

S.; Wang, Z.; Wang, Q. Mineralization

of High-Concentration Aqueous

Aniline by Hybrid Process. Water

2022, 14, 630. https://doi.org/

$10.3390 / w 14040630$

Received: 11 January 2022

Accepted: 14 February 2022

Published: 18 February 2022

Publisher's Note: MDPI stays neutral with regard to jurisdictional claims in published maps and institutional affiliations.

Copyright: (C) 2022 by the authors. Licensee MDPI, Basel, Switzerland. This article is an open access article distributed under the terms and conditions of the Creative Commons Attribution (CC BY) license (https:/ / creativecommons.org/licenses/by/ $4.0 /)$.
College of Chemical Engineering and Environment, China University of Petroleum-Beijing, Beijing 102249, China; zhys01@cup.edu.cn (Y.Z.); cupgsh@163.com (S.G.); 2019592037@cupk.edu.cn (Z.W.); wangqing961018@163.com (Q.W.)

* Correspondence: zhanghaibing@cupk.edu.cn; Tel.: +86-990-663-3303

\begin{abstract}
The efficient mineralization of high-concentration aqueous aniline (HCAA) is an issue needing to be resolved. In this study, a hybrid process of ozonation and electrochemical oxidation (ECO) was proposed for improving the mineralization of HCAA $\left(1000 \mathrm{mg} \cdot \mathrm{L}^{-1}\right)$. The results indicated that chemical oxygen demand (COD) removal by the hybrid process was far greater than that of a single ozonation or ECO process, revealing that the hybrid process might avoid low efficiency in late ozonation and initial ECO. Thus, a subsequent combination effect clearly existed. In this hybrid process, ozonation stage time was selected as $60 \mathrm{~min}$ for optimal COD removal. The main products of the ozonation stage were maleic and succinic acids, with declining $\mathrm{pH}$ which was beneficial to the following ECO stage. Nitrite and nitrate formed during ozonation, which acted as electrolytes for the ECO stage, in which maleic and succinic acids were fully degraded and $\mathrm{pH}$ thus increased. Moreover, the aniline degradation mechanism of the hybrid process was deduced, demonstrating the superiority of this hybrid process. Finally, more than 95\% COD removal was achieved, which met the COD limit requirement and achieved $\mathrm{pH}$ control simultaneously, according to the discharge standards of water pollutants for dyeing and finishing of the textile industry in China (GB 4287-2012).
\end{abstract}

Keywords: aniline; hybrid process; mineralization; ozonation; ECO

\section{Introduction}

Aniline is commonly used by the chemical industry in several processes, such as for producing synthetic paints, antioxidants, herbicides, and varnishes [1-3]. Table 1 exhibits the main sources of aniline pollution in water. This chemical exhibits significant accumulation in nature due to its low degradability [4-6]. The carcinogenicity, teratogenicity, and mutagenicity of aniline have been widely reported due to its long-term persistence in the environment and potential for accumulating in organisms [7-9]. Strict standards have been set for the discharge of aniline wastewater (AW) in many countries and it is necessary for AW to be thoroughly treated before release to nature.

The treatment methods for AW mainly include adsorption, biodegradation, membrane separation, and photocatalytic oxidation [10-14]. Adsorption technology is suitable for low-concentration AW due to its limited adsorbing capacity [15], such that its adsorbing material requires frequent regeneration for treating high-concentration AW. Biodegradation needs a long culture cycle to achieve suitable results with existing biological strains and high-concentration AW and, thus, the degradation rate is slow [16]. Membrane separation can enrich low-concentration AW and act as a pretreatment process [17], but it rarely used for high-concentration AW. Photocatalytic oxidation requires additional artificial UV light to increase aniline mineralization, leading to high treatment costs [18]. Advanced oxidation processes (AOPs) have attracted increasing interest in recent years, owing to their high-degradation efficiency and short treatment period for organic wastewater treatment [19-21]. Among AOPs, ozonation and electrochemical oxidation (ECO) processes are widely used in wastewater treatment. In general, ozonation efficiency is high in its initial 
period. However, ozone oxidizes high-concentration aniline incompletely, even though a catalyst is present [22-24], and efficiency clearly declines over time. ECO exhibits excellent degradation of refractory compounds in aqueous solution [25-28], but in the initial ECO stage, high-concentration aniline polymerization frequently occurs [29-31], which lowers anode oxidation ability. Thus, it is necessary to improve AOPs efficiency for thoroughly mineralizing HCAA.

Table 1. Main sources of aniline pollution in water.

\begin{tabular}{ccc}
\hline Industries & Role of Aniline & Wastewater Kinds \\
\hline synthetic paints & raw material & paint \\
dyestuffs & raw material of dyes and auxiliaries & rubber \\
rubbers & vulcafor, ingredients raw material & pesticide \\
pesticides & raw material & plastic \\
plastics & intermediate & pharmaceutical \\
pharmaceuticals & raw material and intermediate & .
\end{tabular}

Based on the characteristics of ozonation and ECO for treating HCAA, a hybrid process of ozonation and ECO was examined here for possible improvement of the oxidation efficiency for HCAA. To the best of our knowledge, a hybrid process of ozonation and ECO has been little reported regarding the oxidation of such solutions and thus first proposed here. Additionally, the intermediate products and basic mechanism of this hybrid process needed to be revealed.

In this study, HCAA was degraded by a hybrid process, with the purposes of: (1) comparing the effects of the single processes and hybrid process; (2) investigate and optimize the key factors of the hybrid process; and (3) explore the decomposition mechanism of HCAA by the hybrid process.

\section{Materials and Methods}

\subsection{Materials}

Aniline $\left(\mathrm{C}_{6} \mathrm{H}_{7} \mathrm{~N}, \mathrm{M}_{\mathrm{av}} 93.13 \mathrm{~g} / \mathrm{mol}\right)$ sodium hydroxide $\left(\mathrm{NaOH}, \mathrm{M}_{\mathrm{av}} 40.01 \mathrm{~g} / \mathrm{mol}\right)$ and activated carbon (AC; particle size $200 \pm 50 \mu \mathrm{m}$ ) were obtained from Aladdin Industrial Corp., City Industry, CA, USA. All other chemicals were purchased from Sinopharm Chemical Reagent Co., Ltd., Shanghai, China. All chemicals were analytical grade and used as received without further purification. All solutions were prepared using ultrapure water.

\subsection{Ozonation Device}

The removal of aniline from aqueous solution by ozonation was carried out in a cylindrical laboratory-scale reactor $(800 \mathrm{~mL})$. In each experiment, the reactor was filled with $500 \mathrm{~mL}$ of $1000 \mathrm{mg} \cdot \mathrm{L}^{-1}$ aqueous aniline (AA), with ozone produced from pure oxygen via an ozone generator (BMT 802X, BMT Messtechnik GmbH, Stahnsdorf, Germany). Experiments were performed at constant gas flow (measured at $25^{\circ} \mathrm{C}$ and $1 \mathrm{~atm}$ ) and constant inlet ozone concentration $\left(50 \mathrm{~g} \cdot \mathrm{m}^{-3}\right)$. Ozone entered the reactor through a gas distributor in the reactor bottom and was agitated in the solution. AA was prepared in purified water (Milli-Q Advantage A10, Millipore Corp., Billerica, MA, USA) and input to the reactor by a peristaltic pump. The ozone concentration was measured by an ozone analyzer (BMT 964, BMT Messtechnik GmbH, Stahnsdorf, Germany). In an experiment, $350 \mathrm{mg}$ of modified AC (described below) were introduced in the reactor for promotion of ozonation reactions [32]. Ozone gas leaving the reactor was removed before venting in gas-washing bottles filled with $10 \%$ potassium iodide solution.

\subsection{Electrochemical Oxidation Device}

A $500 \mathrm{~mL}$ electrochemical reactor was assembled with a plate-shaped anode $\left(\mathrm{Ti} / \mathrm{SnO}_{2}-\right.$ $\mathrm{Sb}_{2} \mathrm{O}_{3}, 10 \times 10 \mathrm{~cm}$, Xinhengtai New Material Technology Co., Ltd., Xi'an, China) and cathode (SS316 plate, $10 \times 10 \mathrm{~cm}$, Xinhengtai New Material Technology Co., Ltd., Xi'an, China), 
which was vertically positioned in the electrochemical reactor, spaced $3 \mathrm{~cm}$ apart. One end of each electrode was connected to a direct current (DC) power supply, which supplied voltage and current density at $0-30 \mathrm{~V}$ and $25 \mathrm{~mA} \cdot \mathrm{cm}^{-2}$. Compressed air was introduced at the reactor bottom as the oxygen supply through a gas distributor and solution stirred at room temperature $\left(25^{\circ} \mathrm{C}\right)$. For the hybrid process, the entering solution was from the ozonation device. For the single ECO process, the aniline concentration was the same as that in the ozonation experiment.

\subsection{The Hybrid Process}

The hybrid process was assembled by connecting the ozonation and ECO processes (Figure 1, dotted line). Initially, AA is treated by ozonation and then the resulting solution mineralized by ECO.

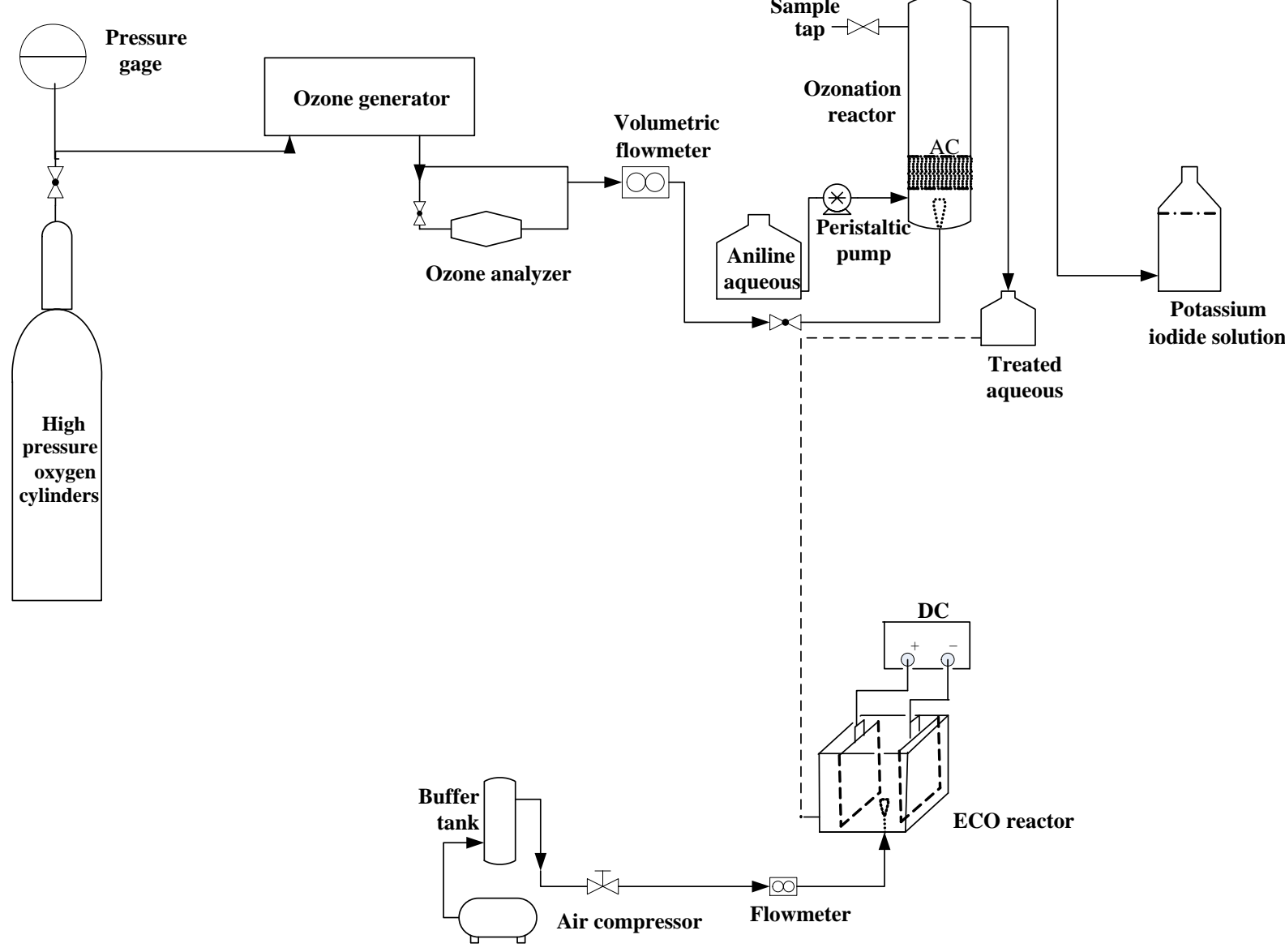

Figure 1. Schematic view of the ozonation process, ECO process, and hybrid process.

\subsection{Modification of Activated Carbon (AC)}

AC was modified using the following steps:

1. The material was washed with deionized water until the washing effluent was nearly colorless and then dried in a hot air oven at $105{ }^{\circ} \mathrm{C}$ for $2 \mathrm{~h}$;

2. A $40 \mathrm{~mL}$ volume of $30 \%$ ( $\mathrm{wt} \%) \mathrm{NaOH}$ aqueous was added to $20 \mathrm{~g}$ of dried $\mathrm{AC}$, oscillated for $2 \mathrm{~h}$ at $30^{\circ} \mathrm{C}$, allowed to sediment for $24 \mathrm{~h}$, and then filtered to remove retrieve the solid;

3. The modified $\mathrm{AC}$ was dried in an oven at $100{ }^{\circ} \mathrm{C}$ for $2 \mathrm{~h}$, rinsed with ionized water to neutrality, dried for $24 \mathrm{~h}$ at $105^{\circ} \mathrm{C}$, and then dried.

The modified $\mathrm{AC}$ was labeled $\mathrm{ACm}$. Before an ozonation experiment, $\mathrm{ACm}$ was soaked in the aqueous aniline (1000 mg. $\left.\mathrm{L}^{-1}\right)$ for $24 \mathrm{~h}$ to eliminate adsorption effects. 


\subsection{Analytical Methods and Procedures}

Conductivity was measured using a conductivity meter (Multi 3630, WTW, Xylem, Inc., Rye Brook, NY, USA). Aniline, $\mathrm{COD}$, ammonia nitrogen $\left(\mathrm{NH}_{4}{ }^{+}-\mathrm{N}\right)$, nitrate-nitrogen $\left(\mathrm{NO}_{3}{ }^{-}-\mathrm{N}\right)$, and nitrous nitrogen $\left(\mathrm{NO}_{2}{ }^{-}-\mathrm{N}\right)$ were measured according to the standard protocol of the State Environmental Protection Administration of China [33].

Aniline oxidation products were detected using a liquid chromatograph with a mass spectrometer (LC-MS; LC-Orbitrap MS, Thermo Fisher Scientific Inc., Pittsburgh, PA, USA). Mobile phase A was ultrapure water containing 0.1 -vol\% formic acid and mobile phase B analytically pure grade methanol (distillation purified) with 0.1 -vol\% formic acid. The LC column was a UPLC $C_{18}$ column (Hypersil Gold Vanquish, $1.9 \mu \mathrm{m}, 100 \times 2.1 \mathrm{~mm}$, Thermo Fisher Scientific, Inc., Waltham, MA, USA).

Polymeric products formed in the initial ECO process were detected by gas chromatography with MS (GC-MS; Agilent 7890a, Agilent Technologies, Inc., Santa Clara, CA, USA and Waters GCT Premier, Waters Corp., Milford, MA, USA, respectively). Carrier gas was $99.999 \%$ nitrogen at $1 \mathrm{~mL} / \mathrm{min}$. Sample quantity was $0.2 \mu \mathrm{L}$ and inlet temperature $280{ }^{\circ} \mathrm{C}$. The chromatographic column was a fused quartz capillary column (HP-5MS, $30 \mathrm{~m} \times 0.25 \mathrm{~mm} \times 0.25 \mu \mathrm{m}$, Agilent Technologies, Inc., Santa Clara, CA, USA). The column's initial temperature was $40{ }^{\circ} \mathrm{C}$ for $5 \mathrm{~min}$, programmed heating at $8^{\circ} \mathrm{C} / \mathrm{min}$ to $240{ }^{\circ} \mathrm{C}$, and then retained for $20 \mathrm{~min}$.

The treatment effect of AA was assessed using the discharge standards of water pollutants for dyeing and finishing of textile industry in China (GB 4287-2012). The main indices are listed in Table 2.

Table 2. Main index limited in discharge standard (GB 4287-2012).

\begin{tabular}{cc}
\hline Index & Indirect Discharge Limited Value \\
\hline $\mathrm{pH}$ & $6-9$ \\
$\mathrm{COD}\left(\mathrm{mg} \cdot \mathrm{L}^{-1}\right)$ & 200 \\
$\mathrm{BOD}_{5}\left(\mathrm{mg} \cdot \mathrm{L}^{-1}\right)$ & 50 \\
Chroma & 80 \\
Ammonia-nitrogen $\left(\mathrm{mg} \cdot \mathrm{L}^{-1}\right)$ & 30 \\
Total nitrogen $\left(\mathrm{mg} \cdot \mathrm{L}^{-1}\right)$ & 50 \\
Total phosphorus $\left(\mathrm{mg} \cdot \mathrm{L}^{-1}\right)$ & 1.5 \\
Aniline $\left(\mathrm{mg} \cdot \mathrm{L}^{-1}\right)$ & 1.0 \\
\hline
\end{tabular}

It should be noted that indirect discharge means the act of enterprises discharging pollutants into a public sewage treatment system. In most cases, enterprises are inclined to indirect discharge and, therefore, meeting the indirect discharge standard is the treatment goal for AA in this study. In the discharge standard, COD is the important index and COD removal thus used here to evaluate oxidation effects.

\section{Results and Discussion}

\subsection{Comparation of Three Oxidation Process}

\subsubsection{Aniline Concentration and COD Removal}

In previous studies, phosphate buffer has been frequently added to AA to control ozonation $\mathrm{pH}[32,34,35]$. However, added phosphate buffer increases the treatment cost and leads to the subsequent difficulties of biological dephosphorization. Therefore, in this study, all experiments were conducted without an aqueous buffer. Sodium chloride $(\mathrm{NaCl}$, $0.5 \mathrm{~g} / \mathrm{L}$ ) was added as the electrolyte for ECO. In the hybrid process, the initial ozonation stage lasted $40 \mathrm{~min}$ and the following $120 \mathrm{~min}$ was the ECO stage. The evolution of the dimensionless aniline concentration and COD removal with time are shown in Figure 2. 

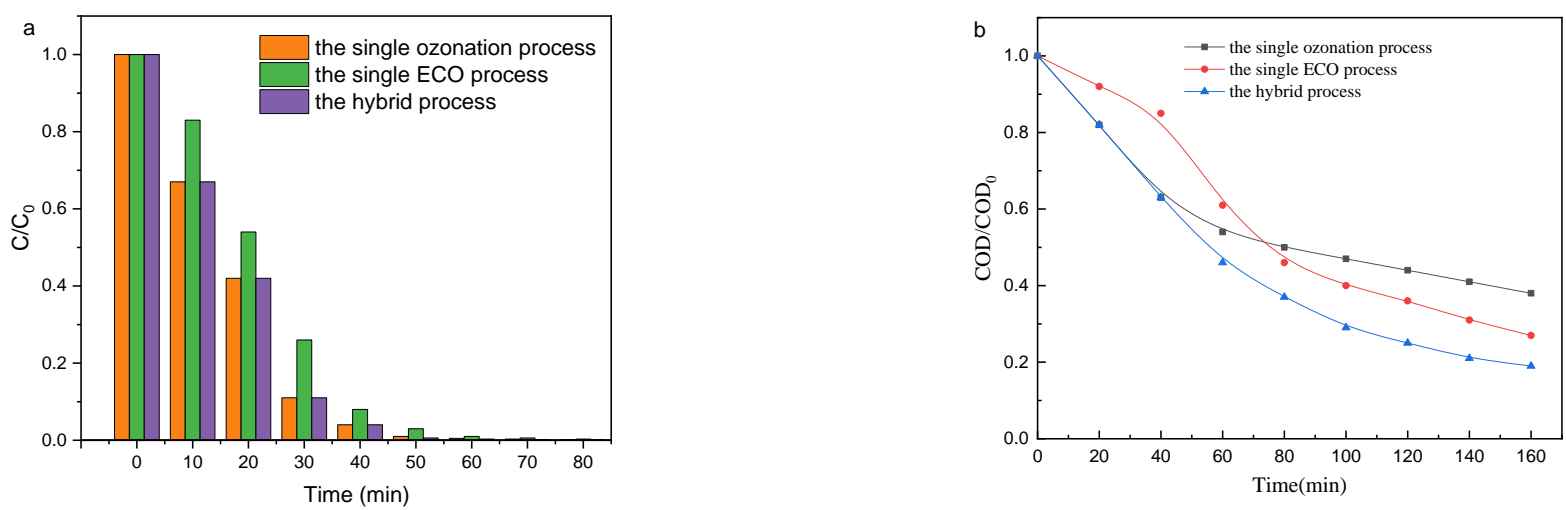

Figure 2. Index changes during the three processes. Removal performance of aniline (a) and COD (b).

In all cases, a fast decay of aniline concentration was observed and complete removal achieved after $\sim 60 \mathrm{~min}$ (Figure 2a). Considering only aniline removal, there was no great advantage in the hybrid process. However, when observing COD removal, the advantage of the hybrid process became clear (Figure $2 b$ ). When the effect of COD removal by the single ozonation process was compared with the single ECO process, it was observed that COD removal by the single ozonation process was higher than that of the single ECO in the first $75 \mathrm{~min}$, while the opposite trend occurred after this period. According to previous reports, aniline is catalytically decomposed by $\cdot \mathrm{OH}$ radicals in the initial single ozonation period. The oxidant species is highly reactive and degrades aniline in a short time, which shows that the indirect ozonation reaction has a dominant role. However, here, the direct ozonation reaction gradually took the leading role as intermediates formed which lowered the $\mathrm{pH}$ over time. As is well known, the reaction rate of direct ozonation is much less than that of indirect ozonation. Thus, in the single ozonation process of HCAA, COD removal was higher in the initial period than in later stages. In the single ECO process, COD removal was very low $(<15 \%)$ in $40 \mathrm{~min}$. It was found that polymeric products formed in the initial ECO stage might result in electrode fouling as a consequence of the adsorption of polymeric oxidation products on their surfaces, which can lead to low COD removal in initial times of single ECO (Figure 3) [36]. COD removal increased significantly once polymeric products were oxidized on the electrode surface from a constant electrode current supply over time.

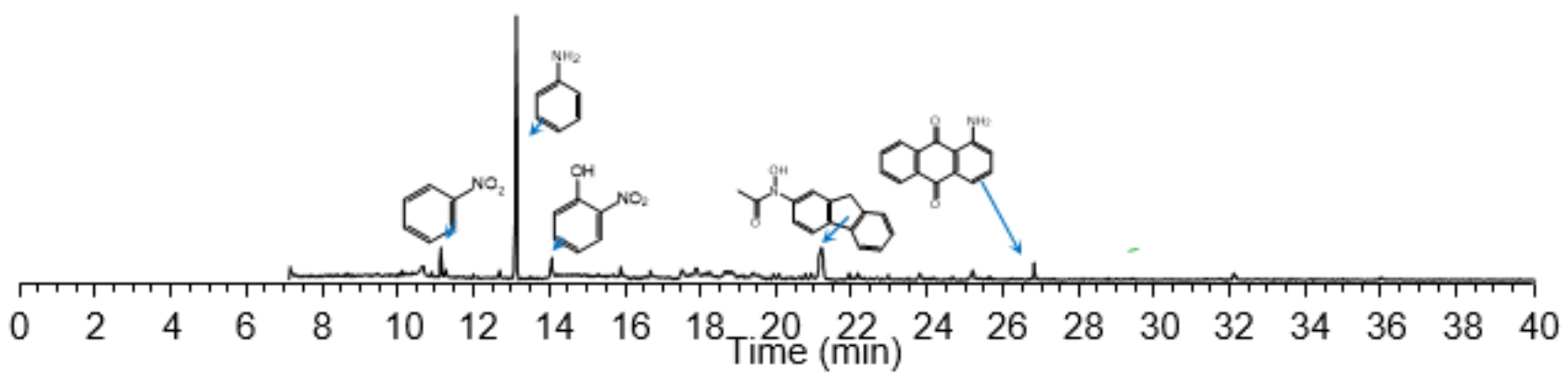

Figure 3. GC-MS analysis of products formed in single ECO process in $10 \mathrm{~min}$.

COD removal of $1000 \mathrm{mg} \cdot \mathrm{L}^{-1}$ AA by the single ozonation, single ECO, and hybrid processes in 160 min was 62, 73, and 81\%, respectively. This indicated that a subsequent combined process effect clearly existed. In the hybrid process, COD removal was higher than that of single ozonation and ECO processes after $40 \mathrm{~min}$. The hybrid process was observed to combine the merits of the two processes and promote COD removal.

\subsubsection{Variation of $\mathrm{pH}$}

Examination of $\mathrm{pH}$ evolution over time during ozonation, ECO, and hybrid processes showed that, due to aniline oxidation products, including carboxylic acid, organic aldehyde, 
or alcohol, $\mathrm{pH}$ significantly decreased with ozonation reactions carried out without buffer conditions, which coincided with preliminary results (Figure 4) [37]. In the ECO reaction, $\mathrm{H}^{+}$was reduced to hydrogen gas on the cathode over time and $\mathrm{OH}^{-}$accumulation raised alkalinity. In the hybrid process, $\mathrm{pH}$ was lowered in the ozonation stage and then gradually increased in the ECO stage, as $\mathrm{H}^{+}$was reduced to a gas. In $\mathrm{ECO}$ under low $\mathrm{pH}$, the oxygen evolution reaction might be inhibited, as the oxidation potential of $\cdot \mathrm{OH}$ was higher under acidic conditions $(+2.85 \mathrm{~V})$ than under alkaline conditions $(+2.02 \mathrm{~V})$. Under acid conditions, .OH has a stronger oxidation ability, which was beneficial for the following ECO stage and thus improved degradation efficiency [38].

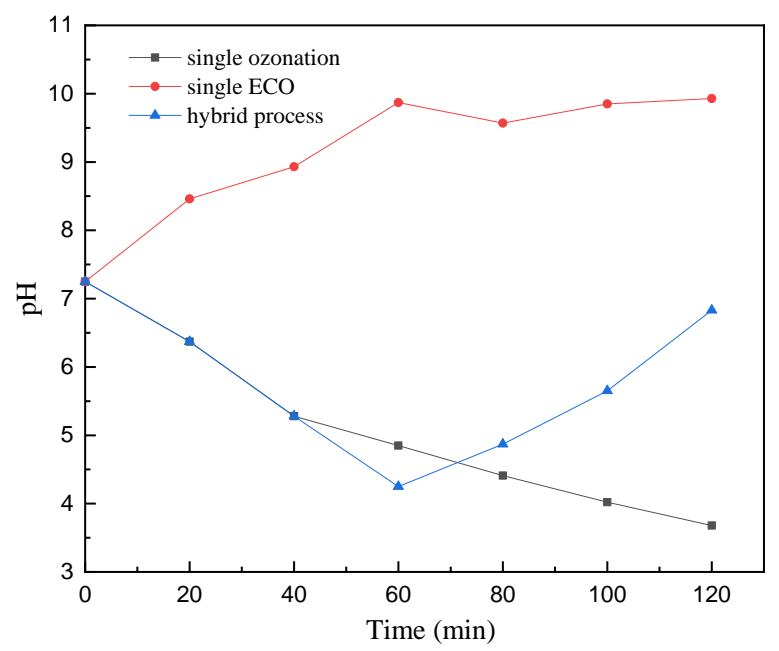

Figure 4. Evolution of $\mathrm{pH}$ of HCAA by ozonation, ECO, and hybrid processes.

\subsubsection{Variation of Nitrogen and Conductivity}

The concentration variations of $\mathrm{NH}_{4}{ }^{+}-\mathrm{N}, \mathrm{NO}_{2}{ }^{-}-\mathrm{N}$, and $\mathrm{NO}_{3}{ }^{-}-\mathrm{N}$ were detected in the oxidation process (Figure 5). In all cases, $\mathrm{NH}_{4}{ }^{+}-\mathrm{N}$ concentrations were low, which indicated that only a little ammonia was converted to $\mathrm{NH}_{4}{ }^{+}$and that most oxidized to $\mathrm{NO}_{2}{ }^{-}$or $\mathrm{NO}_{3}{ }^{-}$. The $\mathrm{NO}_{2}{ }^{-}-\mathrm{N}$ concentration first increased and then declined over time, as in the initial stage, the formation amount of $\mathrm{NO}_{2}{ }^{-}-\mathrm{N}$ was higher than the conversion to $\mathrm{NO}_{3}{ }^{-}-\mathrm{N}$, which led to $\mathrm{NO}_{2}{ }^{-}-\mathrm{N}$ accumulation. After 80 min, most $\mathrm{NO}_{2}{ }^{-}-\mathrm{N}$ was converted to $\mathrm{NO}_{3}{ }^{-}-\mathrm{N}$, with the concentration of $\mathrm{NO}_{3}{ }^{-}-\mathrm{N}$ finally rose to $\sim 140 \mathrm{mg} \cdot \mathrm{L}^{-1}$ (Figure 6). At the same time, most $\mathrm{OH}^{-}$formed in ECO stage was neutralized by $\mathrm{H}^{+}$dissociated from carboxylic acid, which has little help to conductivity improvement.

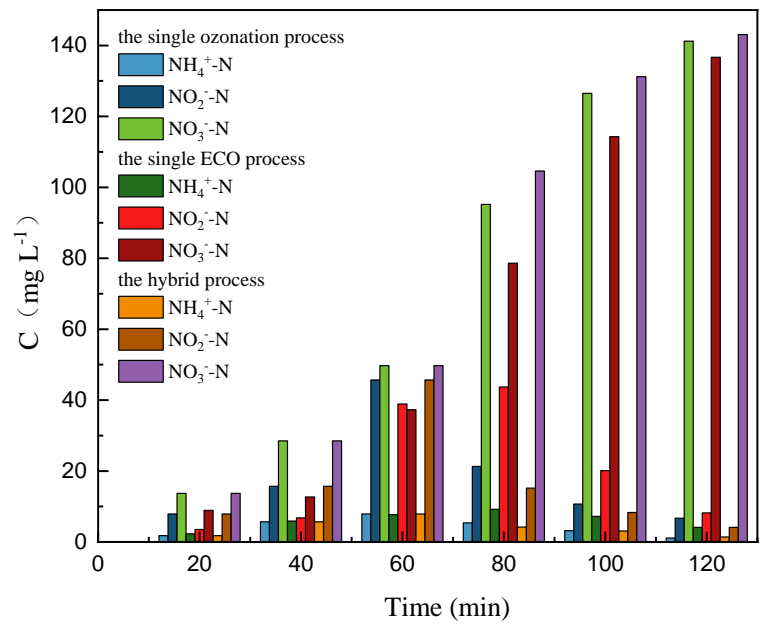

Figure 5. Evolution of concentrations of $\mathrm{NH}_{4}{ }^{+}-\mathrm{N}, \mathrm{NO}_{2}{ }^{-}-\mathrm{N}$, and $\mathrm{NO}_{3}{ }^{-}-\mathrm{N}$ in single ozonation, single $\mathrm{ECO}$, and hybrid processes. 


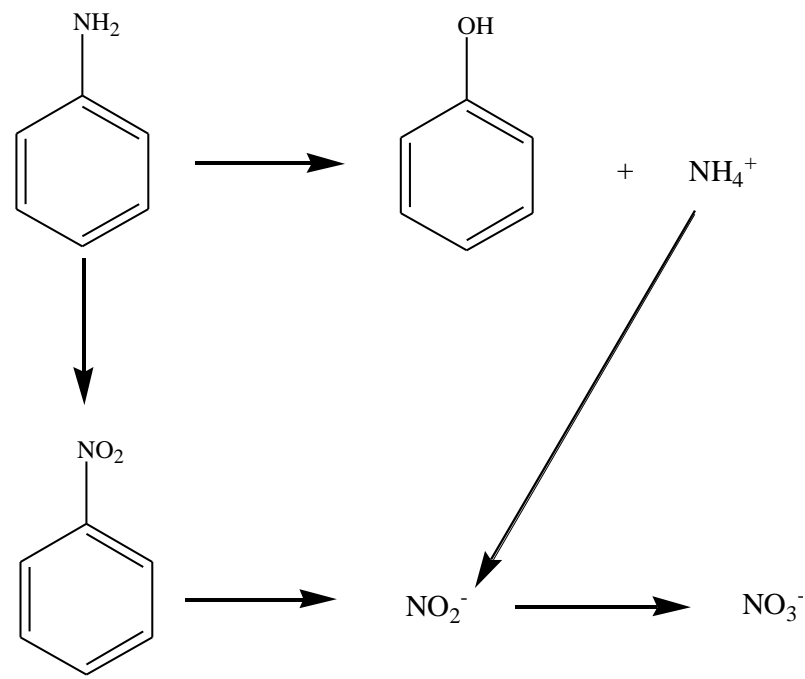

Figure 6. Deduced evolution of $\mathrm{NH}_{4}{ }^{+}, \mathrm{NO}_{2}{ }^{-}$, and $\mathrm{NO}_{3}{ }^{-}$in oxidation process.

Simultaneously, the conductivity of the solution was measured (Figure 7). In the single ozonation process, conductivity increased with increased $\mathrm{NO}_{2}{ }^{-}-\mathrm{N}$ and $\mathrm{NO}_{3}{ }^{-}-\mathrm{N}$ concentrations. In the single ECO process, the initial conductivity was high, which decreased in the first $40 \mathrm{~min}$, and then increased over time. $\mathrm{NaCl}$ addition provided the high initial conductivity and the formation of chlorine or hypochlorous acid $\left(\mathrm{Cl}_{2}\right.$ or $\mathrm{HClO}$, respectively; Equations (1)-(3) caused decreased conductivity in the first $40 \mathrm{~min}$, but the subsequent generation of $\mathrm{NO}_{2}{ }^{-}$and $\mathrm{NO}_{3}{ }^{-}$finally improved conductivity. These results showed that the conductivity difference between single ozonation and ECO was $200-300 \mu \mathrm{s} \cdot \mathrm{cm}^{-1}$ after $40 \mathrm{~min}$. Thus, the formation of $\mathrm{NO}_{2}{ }^{-}-\mathrm{N}$ and $\mathrm{NO}_{3}{ }^{-}-\mathrm{N}$ played an important role in the late period of the single ozonation process and was beneficial for enhancing conductivity for ECO.

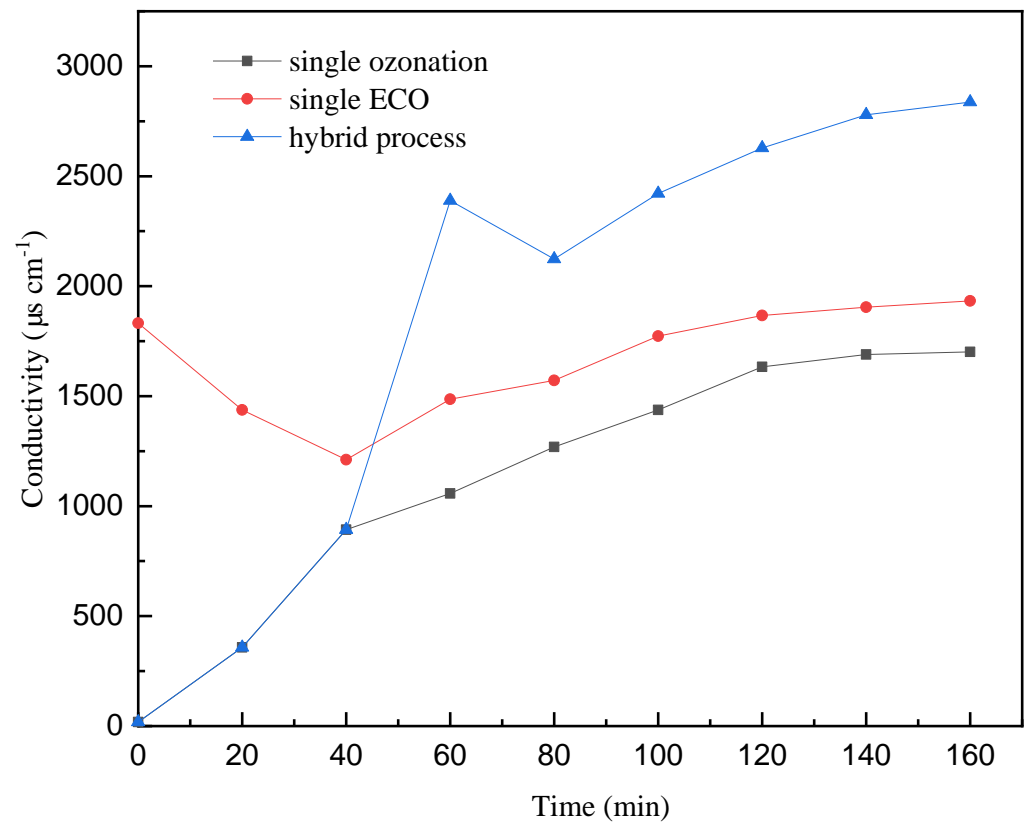

Figure 7. Evolution of conductivity of aniline oxidation by single ozonation, single ECO, and hybrid processes.

In the hybrid process, during the ozonation stage, conductivity gradually increased for the formation of $\mathrm{NO}_{2}{ }^{-}$and $\mathrm{NO}_{3}{ }^{-}$. During the hybrid ECO stage, conductivity increased 
greatly from added $\mathrm{NaCl}$ and the following variation trend the same as for the single ECO process:

$$
\begin{gathered}
2 \mathrm{Cl}^{-} \rightarrow \mathrm{Cl}_{2}+2 \mathrm{e}^{-} \\
\mathrm{Cl}_{2}+\mathrm{H}_{2} \mathrm{O} \rightarrow \mathrm{HClO}+\mathrm{HCl} \\
\mathrm{HClO} \rightarrow \mathrm{H}^{+}+\mathrm{ClO}^{-}
\end{gathered}
$$

\subsection{Optimized Influencing Factors of the Hybrid Process}

\subsubsection{Ozonation Time}

In the hybrid process, ozonation time was crucial for aniline conversion and also impacted the ECO stage efficiency. The influence of different ozonation times on COD removal was examined and maximal COD removal in the hybrid process found to be with $60 \mathrm{~min}$ of ozonation (Figure 8), with COD removal at $95 \%$ of $1000 \mathrm{mg} \cdot \mathrm{L}^{-1} \mathrm{AA}$ and at 81 and $91 \%$ with 40 and 80 min, respectively. It may be seen from Figure $2 \mathrm{~b}$, when ozonation time was $40 \mathrm{~min}, 60 \mathrm{~min}$, and $80 \mathrm{~min}$ in the single ozonation process, the COD removal was $37 \%$, $47 \%$, and $50 \%$ respectively. The COD removal improvement was $10 \%$ when ozonation time from $40 \mathrm{~min}$ prolonged to $60 \mathrm{~min}$, but it was only $3 \%$ when ozonation time prolonged from $60 \mathrm{~min}$ to $80 \mathrm{~min}$. It revealed that these ozonation products formed at $40 \mathrm{~min}$ ozonation may be degraded further by ozonation, while those products formed at 60 min ozonation were difficult to be degraded further by ozonation. On the other hand, Figure 8 indicated that these products formed in $40 \mathrm{~min}$ ozonation were more difficult to be degraded further in the next ECO stage than those products formed in $60 \mathrm{~min}$ or $80 \mathrm{~min}$ ozonation, which led to a stronger decrease of COD for $60 \mathrm{~min}$ and $80 \mathrm{~min}$ than that of $40 \mathrm{~min}$. Therefore, the products formed with $60 \mathrm{~min}$ ozonation were ideal intermediates for the hybrid process. It was more efficient to select $60 \mathrm{~min}$ as the ozonation time for the whole COD removal in the same reaction time. At the same time, Figure 5 showed most of amino were converted to $\mathrm{NH}_{4}{ }^{+}, \mathrm{NO}_{2}{ }^{-}$, or $\mathrm{NO}_{3}{ }^{-}$in 60 min ozonation stage which was close to these formed in 80 min ozonation, while these ions formed in 40 min ozonation were only half of those formed in 60 min ozonation, which would decrease the conductivity obviously. Thus, the $60 \mathrm{~min}$ was selected as the best ozonation time in the hybrid process.

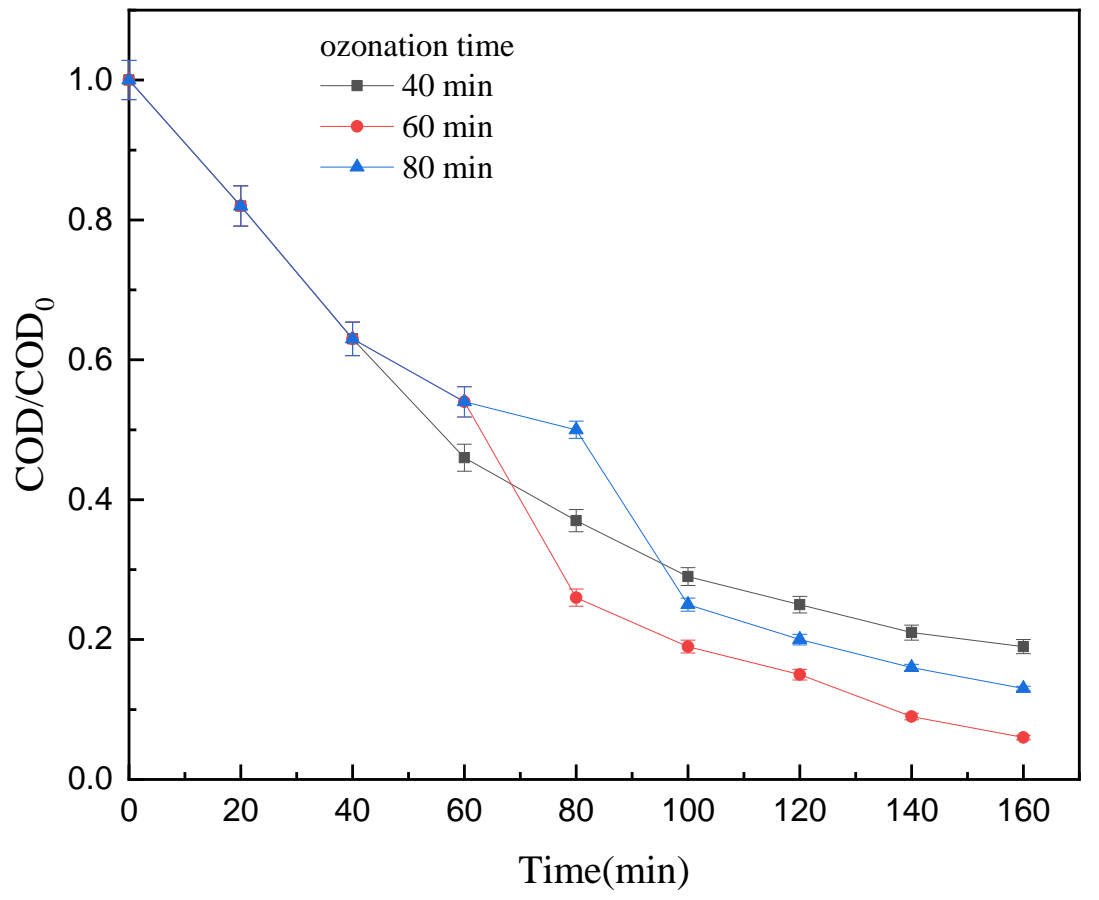

Figure 8. Evolution of COD removal by hybrid process with different ozonation times. 


\subsubsection{Nitrite and Nitrate as Electrolyte}

In the ozonation stage, most of the amino groups were oxidized to nitrite and nitrate, with total concentrations of nitrite and nitrate increased to $\sim 600 \mathrm{mg} \cdot \mathrm{L}^{-1}$ in the ECO stage, which also evidently enhanced conductivity. Thus, it was feasible that nitrite and nitrate replaced $\mathrm{NaCl}$ as the electrolyte at the $\mathrm{ECO}$ stage of the hybrid process. Comparison experiments with no electrolyte addition and different $\mathrm{NaCL}$ additions indicated that COD removal with $1 \mathrm{~g} \cdot \mathrm{L}^{-1} \mathrm{NaCl}$ was superior to that added of $0.5 \mathrm{~g} \cdot \mathrm{L}^{-1}$ or no addition, particularly at 80 to $100 \mathrm{~min}$, from promotion effects by $\mathrm{HOCl}$ (Equations (1)-(3); Figure 9). However, this superiority gradually shrank over time and, finally, COD removal differences between $1 \mathrm{~g} \cdot \mathrm{L}^{-1}$ and no addition were $\sim 2 \%$ by $160 \mathrm{~min}$. In consideration of corrosion resulting from chloride and desalination cost in the next treatment, the hybrid process with no electrolyte was concluded to be the best.

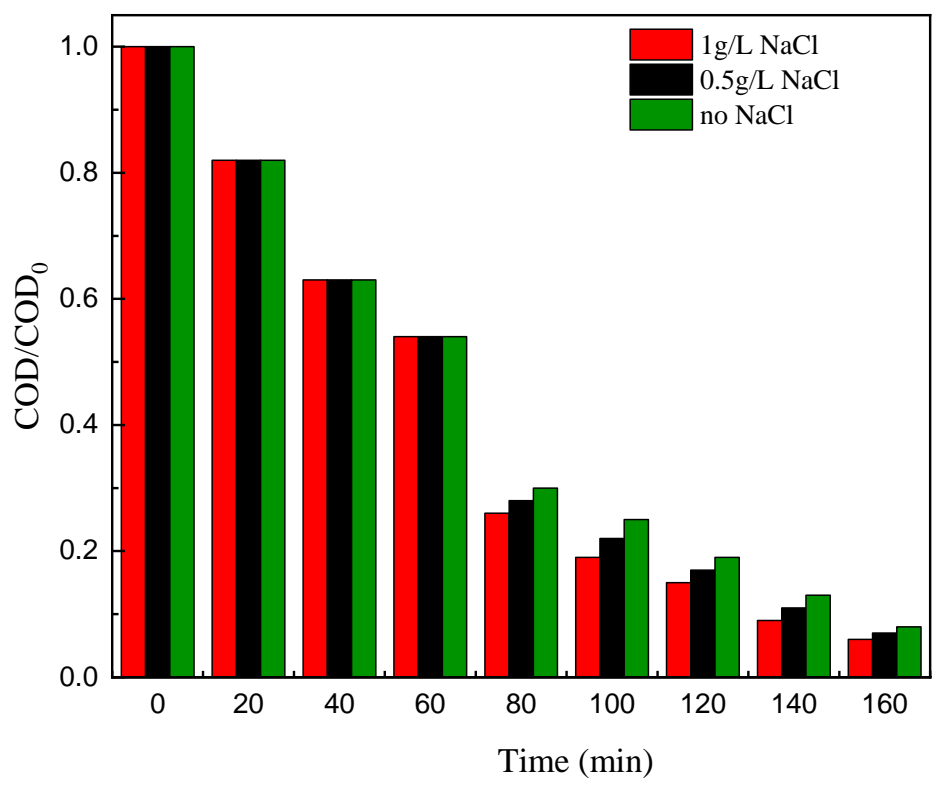

Figure 9. Evolution of $\mathrm{COD}$ removal by hybrid process with different $\mathrm{NaCl}$ concentrations.

\subsubsection{Assessment on the Hybrid Process}

The performance of the hybrid process on $1000 \mathrm{mg} \cdot \mathrm{L}^{-1} \mathrm{AA}$ was assessed by operating the hybrid process without electrolyte. The ozonation stage was $60 \mathrm{~min}$ and ECO for $100 \mathrm{~min}$. Except for total nitrogen, the main indices of AA treated by the hybrid process were in the indirect discharge-limited range (Table 3). Notably, for COD removal and $\mathrm{pH}$, it was difficult to achieve high COD removal and maintain $\mathrm{pH}$ at 6-9 simultaneously for the single processes (Figure 3 ). In the single ozonation process, $\mathrm{pH}$ decreased over time as $\mathrm{COD}$ removal increased. In contrast, in the single ECO process, $\mathrm{pH}$ increased to $>9$ when COD removal reached the discharge standard. However, the hybrid process appeared to improve COD removal and held the $\mathrm{pH}$ in the desired range simultaneously. This fortuitously settled the conundrum regarding high COD removal and $\mathrm{pH}$ controlled in a limited range.

Table 3. Effects of the hybrid process on $1000 \mathrm{mg} \cdot \mathrm{L}^{-1}$ AA solution.

\begin{tabular}{cc}
\hline Item & Hybrid Process \\
\hline $\mathrm{pH}$ & 7.5 \\
$\mathrm{COD}^{\left(\mathrm{mg} \cdot \mathrm{L}^{-1}\right)}$ & 189 \\
$\mathrm{BOD}_{5}\left(\mathrm{mg} \cdot \mathrm{L}^{-1}\right)$ & 46 \\
Chroma & 23 \\
Ammonia-nitrogen $\left(\mathrm{mg} \cdot \mathrm{L}^{-1}\right)$ & 3.3 \\
Total nitrogen $\left(\mathrm{mg} \cdot \mathrm{L}^{-1}\right)$ & 115.8 \\
Anilines $\left(\mathrm{mg} \cdot \mathrm{L}^{-1}\right)$ & 0.8 \\
\hline
\end{tabular}




\subsection{The Merits and Mechanism of Hybrid Process}

During the single ozonation process, the intermediate product variation was observed to include maleic and succinic (butanedioic) acids as the main products after 60 or $120 \mathrm{~min}$ ozonation (Figure 10, Table 4). At low $\mathrm{pH}$, the formation of secondary oxidants, such as . $\mathrm{OH}$, were inhibited and direct oxidation acts as the main reaction for aniline degradation allowed [39]. However, the reaction rate of direct oxidation was much lower than that of $\cdot \mathrm{OH}$ in indirect oxidation. At the same time, aniline was present in its molecular form in neutral or basic conditions. When the solution was acidic, protonated aniline predominated in solution, as the cation anilinium, which was less adsorbed by $\mathrm{AC}_{\mathrm{m}}$ than the corresponding molecular form. Thus, aniline degradation efficiency in ozonation declined significantly when maleic and succinic acids accumulated in late ozonation.
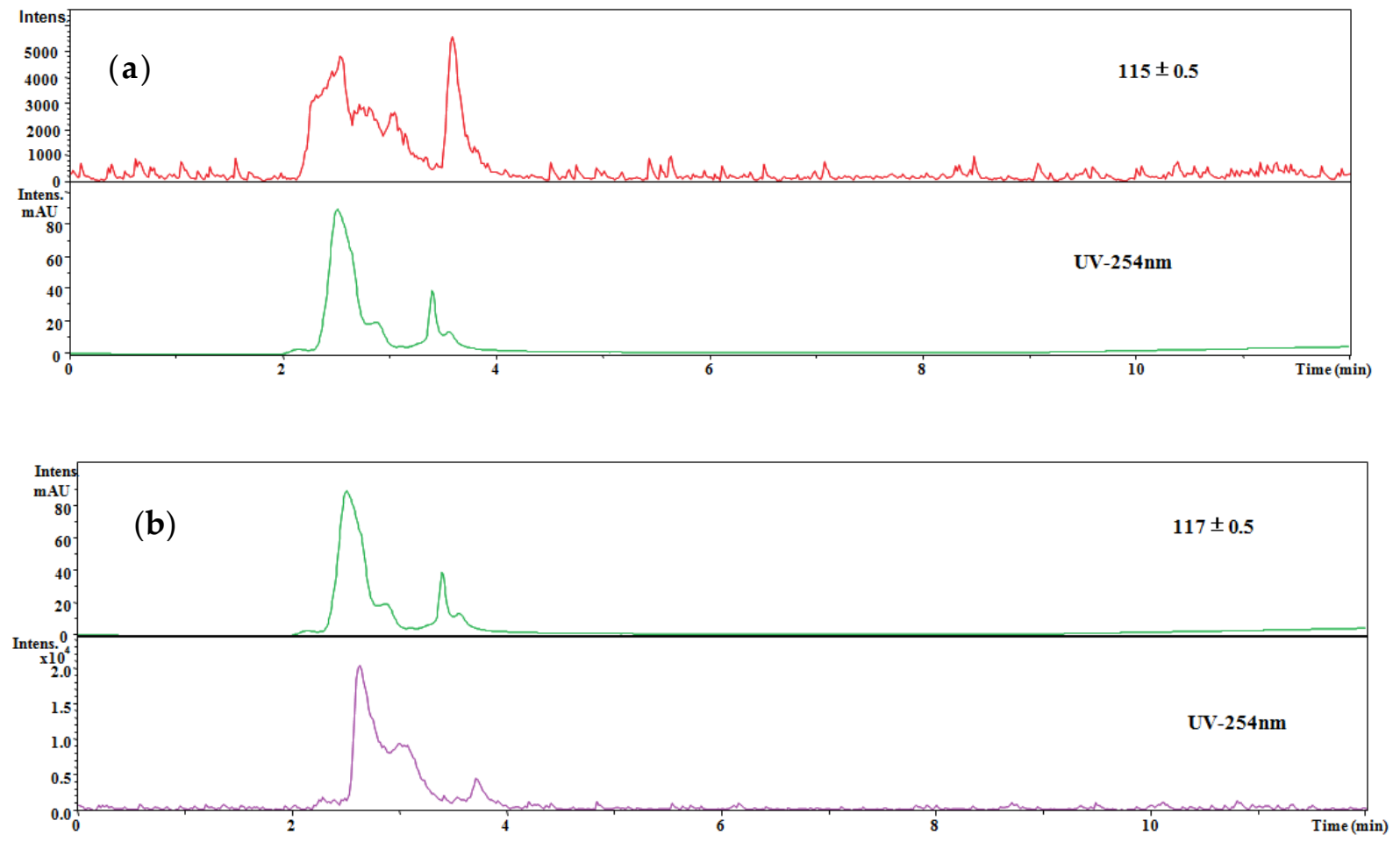

Figure 10. LC-MS analysis of aniline oxidation products in ozonation process at $40 \mathrm{~min}$. (a) maleic acid (a) and succinic acid (b).

Table 4. Peak chart area comparison of intermediates of aniline ozonation.

\begin{tabular}{cccccc}
\hline Intermediate & \multicolumn{5}{c}{ Ozonation Time, min } \\
\cline { 2 - 6 } Products & $\mathbf{1 0}$ & $\mathbf{2 0}$ & $\mathbf{4 0}$ & $\mathbf{6 0}$ & $\mathbf{1 2 0}$ \\
\hline maleic acid & $9,191,232$ & $10,263,980$ & $6,847,330$ & $2,749,407$ & 793,610 \\
p-aminophenol & $1,306,363$ & & & $3,029,264$ & 361,816 \\
succinic acid & & 585,062 & & \\
p-nitrophenol & & $14,714,904$ & 314,472 & \\
benzoquinone & & & $4,896,324$ & \\
\hline
\end{tabular}

In the initial times of single ECO, AA $\left(1000 \mathrm{mg} \cdot \mathrm{L}^{-1}\right)$ reactions were apt to form polymeric products (Table 5). The polymerization reactions were hardly conducive to COD removal, which resulted in electrode fouling and led to increased electrical potential of ECO (from 12.2 to $15.6 \mathrm{~V}$ ). These polymeric products might have been decomposed to $\mathrm{CO}_{2}$ and $\mathrm{H}_{2} \mathrm{O}$ with a constant current supply. However, the potential of ECO was still high (from 14.7 to $15.5 \mathrm{~V}$ ) due to fouled electrodes, which meant that increased energy consumption 
was needed. Thus, the formation of polymeric products in the initial period of the single ECO process was a critical issue for HCAA treatment.

Table 5. Peak chart area comparison of intermediate products in single ECO process.

\begin{tabular}{cccccc}
\hline \multirow{2}{*}{$\begin{array}{c}\text { Intermediate } \\
\text { Products }\end{array}$} & $\mathbf{1 0}$ & $\mathbf{2 0}$ & $\mathbf{4 0}$ & $\mathbf{6 0}$ & $\mathbf{2 0 0}$ \\
\cline { 2 - 6 } & $3,732,405$ & $4,341,021$ & $6,001,241$ & $11,612,253$ & $2,994,023$ \\
\hline maleic acid & $4,041,304$ & & & \\
\hline$p$-aminophenol & $1,633,427$ & & \\
\hline quinoline & $1,134,261$ & & \\
\hline dimethylbenzidine & & $1,214,627$ & \\
\hline $\begin{array}{c}\text { diphenylamine } \\
\text { ethylene diketone }\end{array}$ & & & \\
\hline
\end{tabular}

In the hybrid process, the main products of the ozonation stage were maleic and succinic acids, which clearly decreased the $\mathrm{pH}$ and inhibited radical $\cdot \mathrm{OH}$ formation from $\mathrm{O}_{3}$. Simultaneously, low $\mathrm{pH}$ might inhibit the oxygen evolution reaction and improve the oxidation potential of $\cdot \mathrm{OH}$. Thus, the ozonation stage laid a perfect foundation for the ECO stage. In the ECO, in which maleic and succinic acids were completely mineralized to $\mathrm{CO}_{2}$ and $\mathrm{H}_{2} \mathrm{O}$, providing excellent degradation of carboxylic acids [40-42], and avoiding the formation of polymeric products. The decomposition mechanism of the hybrid process is shown in Figure 11. In the ozonation stage, aniline first reacted with $\cdot \mathrm{OH}$ to form $p$-aminophenol, which was then gradually oxidized to $p$-nitrophenol, hydroquinone, and benzoquinone, with maleic and succinic acids the main products by the end of the ozonation stage. In the ECO stage, maleic and succinic acids were decomposed thoroughly to $\mathrm{CO}_{2}$ and $\mathrm{H}_{2} \mathrm{O}$. The hybrid process combined the merits of the ozonation and ECO processes and effectively avoided the low COD removal efficiency in late ozonation as well as in initial ECO.

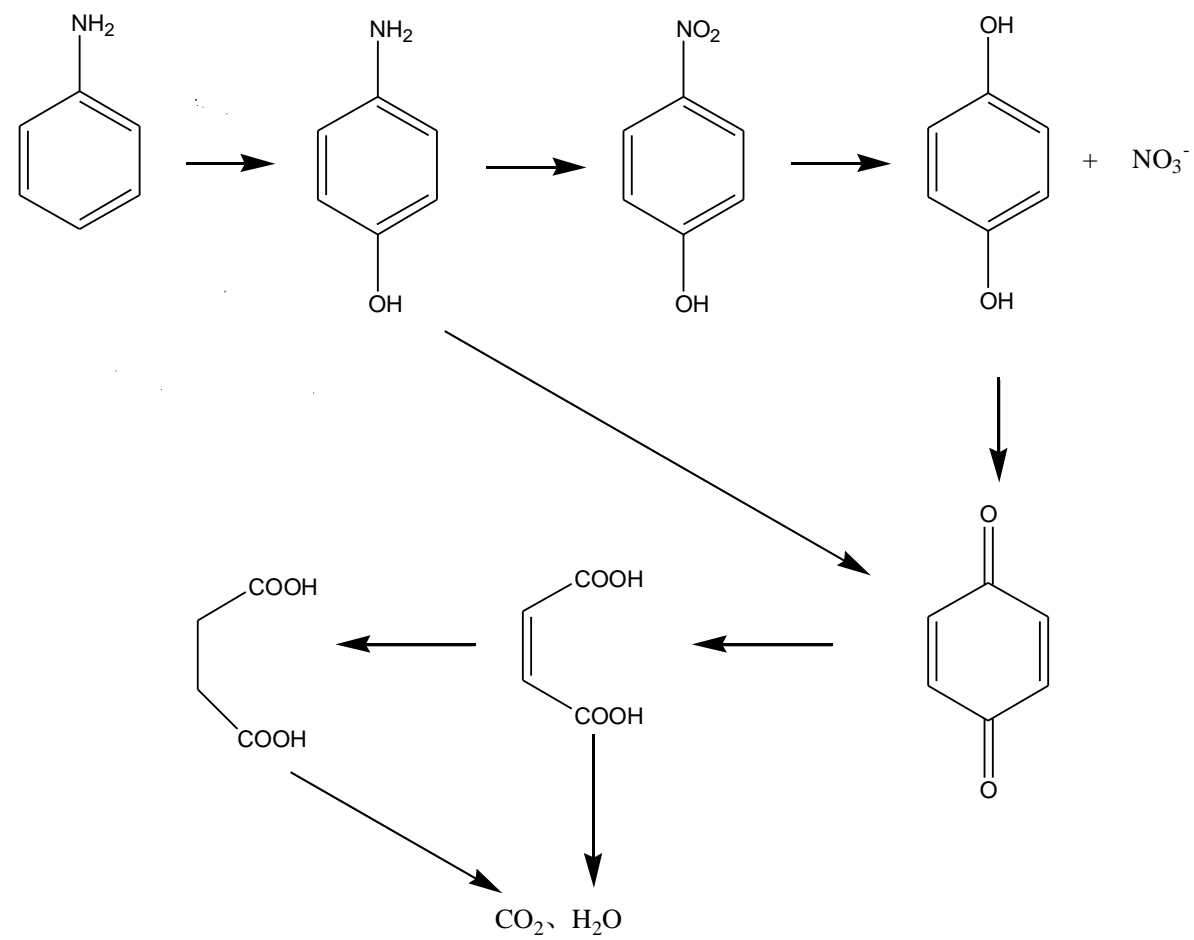

Figure 11. Aniline decomposition mechanism in the hybrid process. 


\section{Conclusions}

A hybrid process, including ozonation and ECO stages, was successfully used to mineralize HCAA and the overall process investigated. The subsequent combination effects on COD removal of the hybrid process were clearly observed. The ozonation stage time was selected to be $60 \mathrm{~min}$ for optimal COD removal. Nitrite and nitrate were considered to be excellent electrolytes for the hybrid process because of self-formation and no corrosion. The results showed that the hybrid process achieved $95 \%$ COD removal and settled the issue between COD removal and $\mathrm{pH}$ range (6-9) limits in the discharge standards. The aniline decomposition mechanism of the hybrid process indicated that maleic and succinic acids were the main products by the end of the ozonation stage, which were subsequently thoroughly decomposed to $\mathrm{CO}_{2}$ and $\mathrm{H}_{2} \mathrm{O}$ in the ECO stage. The hybrid process combined the merits of single ozonation and ECO processes and effectively avoided low efficiency in late ozonation and initial ECO.

Author Contributions: Y.Z. performed the conceptualization; S.G. carried out the design of methodology and analyses; H.Z. and Z.W. contributed process validation; H.Z. and Q.W. performed the investigation; H.Z. wrote the original draft, including preparation, review, and editing; and H.Z. acquired the funding. All authors have read and agreed to the published version of the manuscript.

Funding: This research was supported by Science Foundation of China University of PetroleumBeijing At Karamay (No. RCYJ2016B-02-005 and RCYJ2016B-02-005), the Natural Science Foundation (Tian Shan Qing Nian) of Xinjiang (No. 2020Q021).

Acknowledgments: The authors are thankful for the analysis support by The State Key Laboratory of Heavy Oil. All authors are grateful for the support of the Research Foundation of China University of Petroleum-Beijing at Karamay.

Conflicts of Interest: The authors declare no conflict of interest.

\section{References}

1. Khan, A.H.; Aziz, H.A.; Khan, N.A.; Dhingra, A.; Ahmed, S.; Naushad, M. Effect of seasonal variation on the occurrences of high-risk pharmaceutical in drain-laden surface water: A risk analysis of Yamuna River. Sci. Total Environ. 2021, 794, 148484. [CrossRef] [PubMed]

2. Khan, N.A.; Ahmed, S.; Farooqi, I.H.; Ali, I.; Vambol, V.; Changani, F.; Yousefi, M.; Vambol, S.; Khan, S.U.; Khan, A.H. Occurrence, sources and conventional treatment techniques for various antibiotics present in hospital wastewaters: A critical review. Trends Anal. Chem. 2020, 129, 115921. [CrossRef]

3. Dias, N.C.; Bassin, J.P.; Sant'Anna, G.L.; Dezotti, M. Ozonation of the dye reactive red 239 and biodegradation of ozonation products in amoving-bed biofilm reactor: Revealing reaction products and degradation pathways. Int. Biodeterior. Biodegrad. 2019, 144, 104742. [CrossRef]

4. Cui, D.; Shen, D.; Wu, C. Biodegradation of aniline by a novel bacterial mixed culture AC. Int. Biodeterior. Biodegrad. 2017, 125, 86-96. [CrossRef]

5. Fana, Y.; Chen, X.; Yao, Z. A novel inhibition mechanism of aniline on nitrification: Aniline degradation competes dissolved oxygen with nitrification. Sci. Total Environ. 2021, 770, 145205. [CrossRef]

6. Chen, H.; Sun, C.; Liu, R. Enrichment and domestication of a microbial consortium for degrading aniline. J. Water Process Eng. 2021, 42, 102108. [CrossRef]

7. Ferreiro, C.; Villota, N.; Lombraña, J.I.; Rivero, M.J. An efficient catalytic process for the treatment of genotoxic aniline wastewater using a new granular activated carbon-supported titanium dioxide composite. J. Clean. Prod. 2019, 228, 1282-1295. [CrossRef]

8. Gan, Y.; Chen, G.; Sang, Y.; Zhou, F.; Man, R.; Huang, J. Oxygen-rich hyper-cross-linked polymers with hierarchical porosity for aniline adsorption. Chem. Eng. J. 2019, 368, 29-36. [CrossRef]

9. Xue, G.; Wang, Q.; Qian, Y. Simultaneous removal of aniline, antimony and chromium by ZVI coupled with $\mathrm{H}_{2} \mathrm{O}_{2}$ : Implication for textile wastewater treatment. J. Hazard. Mater. 2019, 368, 840-848. [CrossRef]

10. Koyuncu, H.; Kul, A.R. Removal of aniline from aqueous solution by activated kaolinite: Kinetic, equilibrium and thermodynamic studies. Colloids Surf. A 2019, 569, 59-66. [CrossRef]

11. Zhang, W.; Zhang, Q.; Li, M. Microbial community and function evaluation in the start-up period of bioaugmented SBR fed with aniline wastewater. Bioresour. Technol. 2021, 319, 124148. [CrossRef] [PubMed]

12. Shao, M.; Li, Y.; Meng, L. Simultaneous removal of antimony, chromium and aniline by forward osmosis membrane: Preparation, performance and mechanism. Desalination 2021, 520, 115363. [CrossRef]

13. Jin, R.; Qiu, Z.; Cheng, W. Photocatalytic degradation of aniline by magnetic nanomaterials $\mathrm{Fe}_{3} \mathrm{O}_{4} @ \mathrm{SiO}_{2} @ \mathrm{BiO}_{1.8} \cdot 0.04 \mathrm{H}_{2} \mathrm{O} / \mathrm{Ag}_{3} \mathrm{PO}_{4}$. Chem. Phys. Lett. 2020, 755, 137747. [CrossRef] 
14. Chena, J.; Shena, C.; Guoa, B. Photocatalytic oxidation of aniline over $\mathrm{MO} / \mathrm{TiO}_{2}(\mathrm{M}=\mathrm{Mg}, \mathrm{Ca}, \mathrm{Sr}, \mathrm{Ba})$ under visible light irradiation. Catal. Today 2019, 335, 312-318. [CrossRef]

15. Ghosh, S.; Malloum, A.; Bornman, C. Novel green adsorbents for removal of aniline from industrial effluents: A review. J. Mol. Liq. 2022, 345, 118167. [CrossRef]

16. Wang, H.; Li, C.; Xu, Q. Mass transport and pervaporation recovery of aniline with high-purity from dilute aqueous solution by PEBA/PVDF composite membranes. Sep. Purif. Technol. 2021, 268, 118708. [CrossRef]

17. Durán, A.; Monteagudo, J.M.; Martín, I.S. Solar photo-degradation of aniline with $\mathrm{rGO} / \mathrm{TiO}_{2}$ composites and persulfate. Sci. Total Environ. 2019, 697, 134086. [CrossRef]

18. Chhaya, V.; Rekhate, J.K. Srivastava. Recent advances in ozone-based advanced oxidation processes for treatment of wastewaterA review. Chem. Eng. J. Adv. 2020, 3, 100031.

19. Xie, H.; Li, J.; Wang, Y. Influencing factors for the Fenton-like of biological sponge iron system and its degradation mechanism of aniline. Process Biochem. 2021, 101, 230-236. [CrossRef]

20. Ou, B.; Wang, J.; Wu, Y. A highly efficient cathode based on modified graphite felt for aniline degradation by electro-Fenton. Chemosphere 2019, 235, 49-57. [CrossRef]

21. Ahmadi, M.F.; da Silva, Á.R.L.; Martínez-Huitle, C.A. Understanding the electro-catalytic effect of benzene ring substitution on the electrochemical oxidation of aniline and its derivatives using BDD anode: Cyclic voltammetry, bulk electrolysis and theoretical calculations. Electrochim. Acta 2021, 369, 137688. [CrossRef]

22. Qi, Y.; Guo, C.; Xu, X. Co/Fe and Co/Al layered double oxides ozone catalyst for the deep degradation of aniline: Preparation, characterization and kinetic model. Sci. Total Environ. 2020, 715, 136982. [CrossRef] [PubMed]

23. Li, Y.; Zhu, J.; Hu, J. Catalytic ozonation for effective degradation of aniline by sulfur-doped copper-nickel bimetallic oxide in aqueous solution. J. Environ. Chem. Eng. 2021, 9, 104953. [CrossRef]

24. Chen, C.; Jia, N.; Song, K. Sulfur-doped copper-yttrium bimetallic oxides: A novel and efficient ozonation catalyst for the degradation of aniline. Sep. Purif. Technol. 2020, 236, 116248. [CrossRef]

25. Zhang, Z.; Yi, G.; Li, P. Electrochemical oxidation of hydroquinone using Eu-doped $\mathrm{PbO}_{2}$ electrodes: Electrode characterization, influencing factors and degradation pathways. J. Electroanal. Chem. 2021, 895, 115493. [CrossRef]

26. Sato, Y.; Zeng, Q.; Meng, L. Importance of Combined Electrochemical Process Sequence and Electrode Arrangements: A Lab-scale Trial of Real Reverse Osmosis Landfill Leachate Concentrate. Water Res. 2021, 192, 116849. [CrossRef] [PubMed]

27. Lee, J.; Cho, W.-C.; Poo, K.-M.; Choi, S.; Kim, T.-N.; Son, E.-B.; Choi, Y.-J.; Kim, Y.M.; Chae, K.-J. Refractory oil wastewater treatment by dissolved air flotation, electrochemical advanced oxidation process, and magnetic biochar integrated system. $J$. Water Process Eng. 2020, 36, 101358. [CrossRef]

28. Deng, Y.; Chen, N.; Feng, C. Degradation of nitrogen-containing refractory organic wastewater using a novel alternating-anode electrochemical system. Sci. Total Environ. 2019, 697, 134161. [CrossRef]

29. Karthikeyan, S.; Viswanathan, K.; Boopathy, R. Three dimensional electro catalytic oxidation of aniline by boron doped mesoporous activated carbon. J. Ind. Eng. Chem. 2015, 21, 942-950. [CrossRef]

30. Nie, C.; Ao, Z.; Duan, X. Degradation of aniline by electrochemical activation of peroxydisulfate at MWCNT cathode: The proofed concept of nonradical oxidation process. Chemosphere 2019, 206, 4324-4338. [CrossRef]

31. Ferreira, M.; Pinto, M.F.; Neves, I.C. Electrochemical oxidation of aniline at mono and bimetallic electrocatalysts supported on carbon nanotubes. Chem. Eng. J. 2015, 260, 309-315. [CrossRef]

32. Faria, P.C.C.; Órfão, J.J.M.; Pereira, M.F.R. Ozonation of aniline promoted by activated carbon. Chemosphere 2002, 67, 809-815. [CrossRef] [PubMed]

33. Chinese, N. Water and Wastewater Monitoring Methods; Chinese Environmental Science Publishing House: Beijing, China, 2002.

34. Tekle-R€ottering, A.; von Sonntag, C.; Reisz, E. Ozonation of anilines: Kinetics, stoichiometry, product identification and elucidation of pathways. Water Res. 2019, 98, 147-159. [CrossRef] [PubMed]

35. Oyama, S.T. Chemical and catalytic properties of ozone. Catal. Rev. 2000, 42, 279-322. [CrossRef]

36. $\mathrm{Li}, \mathrm{X}$.; Shao, D.; Xu, H. Fabrication of a stable Ti/ $\mathrm{TiO}_{\mathrm{x}} \mathrm{H}_{\mathrm{y}} / \mathrm{Sb}-\mathrm{SnO}_{2}$ anode for aniline degradation in different electrolytes. Chem. Eng. J. 2016, 285, 1-10. [CrossRef]

37. Zhao, J.; Zhu, C.Z.; Lu, J. Electro-catalytic degradation of bisphenol A with modified $\mathrm{Co}_{3} \mathrm{O}_{4} / \beta-\mathrm{P}_{\mathrm{b}} \mathrm{O}_{2} /$ Ti electrode. Electrochim. Acta 2014, 118, 169-175. [CrossRef]

38. Arts, A.; de Groot, M.T.; van der Schaaf, J. Current efficiency and mass transfer effects in electrochemical oxidation of $C_{1}$ and $C_{2}$ carboxylic acids on boron doped diamond electrodes. Chem. Eng. J. Adv. 2021, 6, 100093. [CrossRef]

39. Von Gunten, U. Ozonation of drinking water: Part I. Oxidation kinetics and product formation. Water Res. 2000, 37, 1443-1467. [CrossRef]

40. Kesavan, L.; Kalekar, A.M.; Damlin, P. Reduced graphene oxide supported palladium nano-shapes for electrooxidation of oxalic acid. J. Electroanal. Chem. 2019, 847, 113167. [CrossRef]

41. de Queiroz, J.L.A.; da Silva, A.R.L.; de Moura, D.C. Electrochemical study of carboxylic acids with Nb-supported boron doped diamond anode. Part 1: Potentiodynamic measurements and bulk oxidations. J. Electroanal. Chem. 2017, 794, 204-211. [CrossRef]

42. Shih, Y.J.; Huang, C.P.; Chan, Y.H. Electrochemical degradation of oxalic acid over highly reactive nanotextured $\gamma-$ and $\alpha-$ $\mathrm{MnO}_{2}$ /carbon electrode fabricated by $\mathrm{KMnO}_{4}$ reduction on loofah sponge-derived active carbon. J. Hazard. Mater. 2019, 379, 120759. [CrossRef] [PubMed] 